\title{
Field Evaluation and Economic Assessment of Different Insecticides against Cotton Jassid, Amrasca devastans Dist.
}

\author{
Faisal Hafeez, Asad Aslam*, Ayesha Iftikhar, Afifa Naeem, Muhammad Faheem Akhtar and Muhammad \\ Jawad Saleem
}

Entomological Research Institute, Ayub Agricultural Research Institute, Faisalabad, Pakistan

Abstract | Five insecticides (Thiacloprid, Nitenpyram, Thiamethoxam, Acephate and Chlorfenpyr) were
evaluated against Amrasca devastans Dist. on farmer field located in Bahawalpur district at recommended
field doses. The treatments were applied on cotton crop when the jassid population was above ETL level.
The most effective insecticide found was Nitenpyram, having minimum population per leaf $(0.35,0.23$ and
0.31 in 2018 and $0.53,0.33$ and 0.42 in 2019 after 1,3 and 7 days of spray), followed by Chlorfenpyr both
years. However, Acephate was ineffective to control jassid population. Moreover, the order of percentage
population change/reduction is as under: Chlorfenpyr Thaimethoxam> Thiacloprid $>$ Acephate. In addition to
this, economic analysis of both years exhibited the similar descending order/trend in benefit cost ratio (BCR)
as above. So the conservative strategies of using non-selective and conventional insecticides for the control
of sucking fauna, especially against jassid, must be transformed / amended to most selective insect growth
regulators (IGR's) and new chemistry insecticides, that are safe and harmless for nature and environment.
Received $\mid$ February 14,2020; Accepted $\mid$ April 10, 2020; Published | May 15, 2020
*Correspondence | Asad Aslam, Entomological Research Institute, Ayub Agricultural Research Institute, Faisalabad, Pakistan; Email:
mr.awan2233@gmail.com
Citation | Hafeez, F., Aslam, A., Iftikhar, A., Naeem, A., Akhtar, M.F., Saleem, M.J. 2020. Field evaluation and economic assessment of different
insecticides against cotton jassid, Amrasca devastans Dist. Journal of Innovative Sciences, 6(1): 24-29.
DOI $\mid$ http://dx.doi.org/10.17582/journal.jis/2020/6.1.24.29
Keywords $\mid$ Cotton jassid, IGR's, New chemistry insecticides, BCR

\section{Introduction}

C otton, Gossypium birsutum L., is backbone of economy of Pakistan. It plays an important role in foreign exchange soenhance the country's economy. The production of cotton crop is $1 \%$ in GDP while accounts for $5.2 \%$ in agriculture value addition (Anonymous, 2017) and overall production of cotton crop was 8.2 million 480 -pound bales from the area of $2.8 \mathrm{~m}$ ha (Anonymous, 2018).

The attack of sucking insects pests like jassid, $A$. devastans (Dist.), whitefly, Bemisia tabaci (Genn.) and thrips, Thrips tabaci(Lind.) on cotton (Gouda et al., 2014) has been increased due to the growing of BT cotton on extensive areas (Ahsan and Altaf, 2009; Abdullah, 2010) which is specific to chewing insect pests (Arshad et al., 2009) because these varieties are not resistance to sucking insect pests (Sharma and Pampapathy, 2006). Among sucking pests, the jassid, A. devastans, is one of the major and serious pests of cotton. Both adults and nymphs, not only suck the cell sap but also injects toxin, from underside of the leaves. Attacked leaves (first) turn pale and then rust red. The leaves then, turn downward and fall on the ground with increased passage of time. This extended action causes loss of plant vitality, boll drop and reduces yield from $18.75 \%$ to $35 \%$ (Ali, 1992).

There are many methods to manage the jassids like mechanical control, biological control, cultural control etc (Chinniah and Ali, 2000) but Development of resistant varieties is the best and cheapest option to manage the jassid infestation. The most vital 
character to make a jassid resistant variety was leaf hairiness (Krishnananda and Agarwal, 1979; Ahmad et al., 2004). But still this strategy is in the future. The one and only approach, left is the use of chemicals but should onlybe used as last way out (Korejo et al., 2000). Conventional chemicals are non selective and broad spectrum. Repeated use of these chemicals created detoxification in jassid population (Ahmad et al., 1999). The neonictiniods and growth regulators reinstated the previously used pesticides which were proved inefficient (Aheer et al., 2000; Solangi and Lohar, 2007; Aslam et al., 2004; Frank, 2012) due to resistance problems. The use of neonictiniods are supposed to be less toxic to the non-target insects like predators and parasites than other conventional insecticides (Balakrishnan et al., 2009; Sabry and E1-Sayed, 2016). These chemicals are selective and specific, with no side as well as after effects on non target insects and environment (Michaud and Grant, 2003; Sahito et al., 2016).

The present study was therefore conducted to evaluate the efficacy of five presently available insecticides under the field conditions to know that either these insecticides can reduce the population of jassids below economic threshold level (ETL).

\section{Materials and Methods}

\subsection{Study area}

The study was conducted at Bahawalpur during Kharif 2018-19. The variety (FH-118) was sown (09-032018 and 5-02-2019, respectively). The five treatments viz. Thiacloprid 48SC (Talent), Nitenpyram 10SL (Pyramid), Thiamethoxam 25WP (Actara), Acephate 75SP (Coredor) and Chlorfenpyr 360SL (Pyrate), were applied to crops at standard doses in the month of August, when the jassid population reached at ETL.

\subsection{Research design}

The variety (FH-118) was selected and sown on 0903-2018 and 25-02-2019 under randomized complete block design with five treatments and a control. The net plot size was $4.5 \times 18.5 \mathrm{~m}^{2}$ and $9.15 \times 13.72 \mathrm{~m}^{2}$, in 2018 and 2019, respectively. All recommended agronomic strategies was adopted on all treatments.

\subsection{Data collection}

The insecticides were applied on the selected plots by knapsack sprayer with hollow cone nozzle having the pressure of 3 bars. The data was recorded by randomly selecting 20 plants, in each plot. The number of $A$. devastans was counted, from upper leaf of $1^{\text {st }}$ plant, middle leaf of $2^{\text {nd }}$ plant, lower leaf of $3^{\text {rd }}$ plant and then repeats the same sequence. Pre-Treatment data was observed before application of treatments. The population (post treatment) was recorded one day, three days and seven days, after application.

\subsection{Data analysis}

The data was analyzed with computer based software Statistix 8.1, by analysis of variance and means were separated by LSD test at 5\% level of significance. Percent population change/reduction was corrected by using modified Abbotts formula (Flemings and Ratnakaran, 1985). The \%age reduction in population was calculated by using following formula:

\section{Percentage population reduction $=A-B / A \times 100$}

A: Pretreatment population; B: Post treatment population.

\section{Results and Discussion}

Population level of jassid; before and after spray (during 2018 study period) was presented in Table 1. The Pre-treatment data comprised of 2.34-2.57 jassid/leaf (both adult and nymph), which is beyond ETL and spray was recommended. The population per leaf and percent mortality was recorded 1, 3 and 7 days after spray. Maximum decrease in mean per leaf population of jassid, one day after spray was recorded in plots treated with Nitenpyram, Chlorfenpyr, Thiacloprid and Thiamethoxam which was statistically non-significant and higher than that in plot treated with Acephate.

Three days after spray, maximum reduction in jassid population was recorded in plots treated with Nitenpyram followed by Chlorfenpyr and Thaicloprid, that were statistically similar with each other but different from plots treated with Thiamethoxam and Acephate from where minimum decrease in population were recorded. The same trend was recorded seven days after spray.

Population level of jassid during the next growing season i.e. 2019, was presented in Table 2. The Pretreatment population of jassid/leaf was 2.08-2.38 (both adult and nymph) and spray was done. After the spray, the population per leaf and percent mortality was 
Table 1: Post-Treatment/Percent population change (increase or decrease) and mean per leaf population of $A$. devastans (inparenthesis) on different days (before and after spray) in 2018*

\begin{tabular}{lllllll}
\hline Treatments & & $\begin{array}{l}\text { Dose per } \\
\text { hectare }\end{array}$ & \multicolumn{2}{l}{ Pre-Treatment } & \multicolumn{3}{l}{ Post-Treatment / Population Change (+ or -) } \\
\cline { 5 - 7 } Common name & Trade name & 1 Day before & $\begin{array}{l}\text { 1 Day after } \\
\text { spray }\end{array}$ & $\begin{array}{l}\text { 3 Days after } \\
\text { spray }\end{array}$ & $\begin{array}{l}\text { 7 Days after } \\
\text { spray }\end{array}$ \\
\hline Thiacloprid & Talent & $125 \mathrm{ml} / \mathrm{ha}$ & $(2.40)$ & $77.92(0.53) \mathrm{cd}$ & $82.92(0.41) \mathrm{cd}$ & $84.79(0.36) \mathrm{d}$ \\
Nitenpyram & Pyramid & $500 \mathrm{ml} / \mathrm{ha}$ & $(2.43)$ & $85.62(0.35) \mathrm{d}$ & $90.55(0.23) \mathrm{d}$ & $87.26(0.31) \mathrm{d}$ \\
Thiamethoxam & Actara & $60 \mathrm{gm} / \mathrm{ha}$ & $(2.57)$ & $71.56(0.73) \mathrm{c}$ & $76.23(0.61) \mathrm{c}$ & $78.18(0.56) \mathrm{c}$ \\
Acephate & Confidor & $625 \mathrm{gm} / \mathrm{ha}$ & $(2.40)$ & $54.58(1.09) \mathrm{b}$ & $61.67(0.92) \mathrm{b}$ & $63.33(0.88) \mathrm{b}$ \\
Chlorfenpyr & Pyrate & $185 \mathrm{ml} / \mathrm{ha}$ & $(2.44)$ & $81.56(0.45) \mathrm{d}$ & $85.66(0.35) \mathrm{d}$ & $87.09(0.31) \mathrm{d}$ \\
Control & & & $(2.34)$ & $-3.56(2.42) \mathrm{a}$ & $-6.84(2.50) \mathrm{a}$ & $-8.97(2.55) \mathrm{a}$ \\
LSD value & & & 0.39 & 0.25 & 0.25 & 0.09 \\
\hline
\end{tabular}

* Means having same letters are non-significantly different from each other, (LSD; P=0.05). NS: non-significantly different.

Table 2: Post-Treatment / Percent population change (increase or decrease) and mean per leaf population of $A$. devastans (inparenthesis) on different days (before and after spray) in 2019*.

\begin{tabular}{|c|c|c|c|c|c|c|}
\hline \multicolumn{2}{|l|}{ Treatments } & \multirow{2}{*}{$\begin{array}{l}\text { Dose per } \\
\text { hectare }\end{array}$} & \multirow{2}{*}{$\begin{array}{l}\text { Pre-Treatment } \\
1 \text { Day before } \\
\text { spray }^{\text {NS }}\end{array}$} & \multicolumn{3}{|c|}{ Post-Treatment / Population Change (+ or -) } \\
\hline Common Name & Trade Name & & & $\begin{array}{l}1 \text { Day after } \\
\text { spray }\end{array}$ & $\begin{array}{l}3 \text { Days after } \\
\text { spray }\end{array}$ & $\begin{array}{l}7 \text { Days after } \\
\text { spray }\end{array}$ \\
\hline Thiacloprid & Talent & $125 \mathrm{ml} / \mathrm{ha}$ & $(2.08)$ & $66.40(0.70) \mathrm{d}$ & $71.20(0.60) \mathrm{d}$ & $68.80(0.65) \mathrm{d}$ \\
\hline Nitenpyran & Pyramid & $500 \mathrm{ml} / \mathrm{ha}$ & $(2.08)$ & $74.56(0.53) \mathrm{e}$ & $84.00(0.33) \mathrm{f}$ & $79.84(0.42) \mathrm{e}$ \\
\hline Thiamethoxam & Actara & $60 \mathrm{gm} / \mathrm{ha}$ & $(2.27)$ & $58.09(0.95) \mathrm{c}$ & $65.15(0.79) \mathrm{c}$ & $61.18(0.88) \mathrm{c}$ \\
\hline Acephate & Confidor & $625 \mathrm{gm} / \mathrm{ha}$ & $(2.33)$ & $52.86(1.10) \mathrm{b}$ & $58.71(0.96) \mathrm{b}$ & $57.57(0.99) \mathrm{b}$ \\
\hline Chlorfenpyr & Pyrate & $185 \mathrm{ml} / \mathrm{ha}$ & $(2.33)$ & $74.71(0.59) \mathrm{de}$ & $80.43(0.46) \mathrm{e}$ & $79.00(0.49) \mathrm{e}$ \\
\hline Control & & & $(2.38)$ & $-6.99(2.55) \mathrm{a}$ & $-8.25(2.58) \mathrm{a}$ & $-9.51(2.61) \mathrm{a}$ \\
\hline LSD value & & & 0.47 & 0.15 & 0.07 & 0.10 \\
\hline
\end{tabular}

Means having same letters are non-significantly different from each other, (LSD; P=0.05). NS: non-significantly different.

Table 3: Cumulative economic analysis of different insecticides against $A$. devastans of both years.

\begin{tabular}{|c|c|c|c|c|c|c|c|c|}
\hline S.\# & $\begin{array}{l}\text { Average } \\
\text { yield (kg/ha) }\end{array}$ & $\begin{array}{l}\text { Additional } \\
\text { yield (kg/ha) }\end{array}$ & $\begin{array}{l}\text { Total expendi- } \\
\text { ture (Rs/ha) }\end{array}$ & $\begin{array}{l}\text { Additional ex- } \\
\text { penditure (Rs /ha) }\end{array}$ & $\begin{array}{l}\text { Total income } \\
\text { (Rs/ha) }\end{array}$ & $\begin{array}{l}\text { Additional in- } \\
\text { come (Rs/ha) }\end{array}$ & $\begin{array}{l}\text { Net income } \\
\text { (Rs/ha) }\end{array}$ & BCR \\
\hline $\mathrm{T}_{1}$ & $3536.5 \mathrm{c}$ & 150 & $530(88820.15)$ & 530 & 209997.39 & 8907.02 & 121177.24 & 1.364 \\
\hline $\mathrm{T}_{2}$ & $3578.5 \mathrm{a}$ & 192 & $825(89115.15)$ & 825 & 212491.33 & 11400.96 & 123376.18 & 1.384 \\
\hline $\mathrm{T}_{3}$ & $3478.7 \mathrm{~d}$ & 92.7 & $625(88915.15)$ & 625 & 206563.43 & 5473.06 & 117648.28 & 1.323 \\
\hline $\mathrm{T}_{4}$ & $3450.5 \mathrm{e}$ & 64 & 868.75 (89158.9) & 868.75 & 204890.69 & 3800.32 & 115731.79 & 1.298 \\
\hline $\mathrm{T}_{5}$ & $3560.0 \mathrm{~b}$ & 173.5 & 693.75 (88983.9) & 693.75 & 211392.5 & 100302.43 & 122408.9 & 1.376 \\
\hline $\mathrm{T}_{6}$ & $3386.5 \mathrm{f}$ & & $0(88290.15)$ & & 201090.37 & & 112800.22 & 1.278 \\
\hline
\end{tabular}

LSD value 5.93

Where; $\mathrm{T}_{1}$ : Thiacloprid $48 \mathrm{SC}$ (Talent); $\mathrm{T}_{2}:$ Nitenpyram $10 \mathrm{SL}$ (Pyramid); $\mathrm{T}_{3}$ : Thiamethoxam $25 \mathrm{WP}$ (Actara); $\mathrm{T}_{4}$ : Acephate $75 \mathrm{SP}$ (Confidor); $\mathrm{T}_{5}$ : Chlorfenpyr $360 \mathrm{SL}$ (Pyrate); $\mathrm{T}_{6}$ : Control.

recorded, on next 1, 3 and 7 days. Maximum decrease in mean population per leaf, one day after spray was recorded in plots treated with Chlorfenpyr followed by Nitenpyram and Thaicloprid, that were statistically similar with each other but different from plots treated with Thiamethoxam and Acephate having minimum decrease in population were recorded.

Three days after spray, maximum reduction in jassid population was recorded in plots treated Journal of Innovative Sciences

June 2020 | Volume 6| Issue 1 | Page 26 with Nitenpyram followed by Chlorfenpyr and Thaicloprid, that were statistically different with each other whereas plots treated with Thiamethoxam and Acephate having minimum decrease in population were recorded. The same trend was recorded seven days after spray.

The results showed that all treatments/insecticides performed better over control. However, nitenpyram found excellent in reducing the population level (both 
years) of jassid. Our findings are in consonance with Bambhaniya et al., 2018; Khan et al., 2016; Qaiser et al.,2011, who reported that new chemistry insecticides are selective and specific (insect species and insect stage). These groups of insecticides are effective and more toxic to the jassid. In addition to this, Razaq et al. (2005) evaluated neonicotinoids / insect growth regulators (IGR's) against cotton jassid and reported similar findings. However, Eittipibool et al. (2001) found differentiating records that IGR's are the best alternative in contrast to conventional insecticides but their contribution is limited/no, in the population of reduction of jassid because the tested IGR's do not increase hair density/length.

\subsection{Economic analysis of yield}

Nitenpyram treated plots recorded highest yield (3578.5 kg/ha) followed by Chlorfenpyr $(3560 \mathrm{~kg} /$ ha), Thiacloprid (3536.5 kg/ha), Thiamethoxam $(3478.7 \mathrm{~kg} / \mathrm{ha})$, Acephate $(3450 \mathrm{~kg} / \mathrm{ha})$ and control $(3386.5 \mathrm{~kg} / \mathrm{ha})$. The plots treated with Nitenpyram gave significantly higher yield over all other treatments. However, all the treatments showed statistically significant difference among each other. The benefit cost ratio (BCR) was maximum in nitenpyram (1.384) followed by Chlorfenpyr (1.376) and Thiacloprid (1.364), while acephate registered lowest BCR of 1.278 (Table 3). These findings are partially in consonance with Rawale et al. (2002), who reported 11.51 quintal/ha yield of seed cotton when plots are treated with profenophos + cypermethrin. However, in 2018, Rudramuni and his co-workers performed his research work in India and found that all insecticides have differentiating results but have significant superiority over control. Moreover, treated plots yielded 2-10 times more seed cotton than control. In Indian Punjab, cost benefit ratio was estimated on the basis of integrated pest management (IPM) and insect resistance management (IRM) and they (Singh and Singh, 2007) found that the cost benefit ratio is almost doubled with the adoption of with two tools.

These findings are partially in consonance with Rawale et al. (2002), who reported 11.51 quintal/ha yield of seed cotton when plots are treated with profenophos + cypermethrin. However, in 2018, Rudramuni and his co-workers performed his research work in India and found that all insecticides have differentiating results but have significant superiority over control.Moreover, treated plots yielded 2-10 times more seed cotton than control. In Indian Punjab, cost benefit ratio was estimated on the basis of integrated pest management (IPM) and insect resistance management (IRM) and they (Singh and Singh, 2007) found that the cost benefit ratio is almost doubled with the adoption of with two tools.

\section{Conclusions and Recommendations}

From above findings the studies concluded that Nitenpyram was found most effective to control the cotton jassid population below ETL followed by Chlorfenpy while accephate showed least control the pest population. The chemicals had controlled the pests as result it increased the production of cotton significantly. The above used IGRs were found insect specific chemicals and did not harm predator or parasite. So these insecticides can be used as replacement of large spectrum conventional insecticides which are resistant by pests.

\section{Authors Contribution}

Faisal Hafeez: Research planing and collection of data

Asad Aslam: Corresponding Author and help in paper writing.

Ayesha Iftikhar: Statistical analysis of data.

Afifa Naeem: Proof Reading of the research paper.

Muhammad Faheem Akhtar: Collection of data and help in data analysis.

Muhammad Jawad Saleem: Proof Reading of research article.

\section{Conflict of Interest}

The authors have declared no conflict of interest.

\section{References}

Abbas, Q., Arif, M.J., Gogi, M.D., Abbas, S.K. and Karar, H., 2012. Performance of imidacloprid, thiomethoxam, acetamaprid anda biocontrol agent (Chrysoperla carnea) against whitefly, jassid and thrips on different cotton cultivars. World Journal of Zoology, 7(2):141-146.

Abdullah, A., 2010. An analysis of Bt cotton cultivation in Punjab, Pakistan using the Agriculture Decision Support System (ADSS). AgBio Forum, 13: 274- 287.

Aheer, G.M., Ahmad, N. and Karar, H., 2000. 
Chemical control of cotton whitefly adults, Bemisia tabaci (Genn.). Journal of Agriculture Research., 38: 353-357.

Ahmad, M., Arif, M.I. and Ahmad, Z., 1999. Detection of resistance to pyrethroids in field populations of cotton jassid (Homoptera: Cicadellidae) from Pakistan. Journal of Economic Entomology. 92: 1246-1250. https:// doi.org/10.1093/jee/92.6.1246

Ahmad, S., Maqsood, S., Farooq, H.M.K. and Ullah, F., 2004. Resistance of cotton against Amrasca devastans (Dist.) (Jassidae: Homoptera) and relationship of the insect with leaf hair density and leaf hair length. Sarbad Journal of Agriculture. 20(2): 265-268.

Ahsan, R. and Altaf, Z., 2009. Development, adoption and performance of $\mathrm{Bt}$ cotton In Pakistan: A review. Pakistan Journal of Agricultural Sciences. 22: 73-85

Ali, A., 1992. Physio-chemical Factors Affecting Resistance in Cotton against jassid, Amrasca devastans (Dist.) and thrips,Thrips tabaci (Lind.) in Punjab, Pakistan. Ph. D Dissert. Department of Entomology, University of Agriculture, Faisalabad, Pakistan. p. 430.

Arshad, M, Suhail, A, Arif, M.J., Khan, M.A. 2009. Transgenic Bt and non-transgenic cotton effects on survival and growth of Helicoverpa armigera. International Journal of Agriculture and Biology., 11: 473-476.

Anonymous. 2017. Economic survey of Pakistan.

Anonymous. 2018. Economic survey of Pakistan.

Aslam, M., Razaq, M., Shah, S.A. and Ahmad, F., 2004. Comparative efficacy of different insecticides against sucking pests of cotton. Journal of Scientific Research., 15: 53-58.

Balakrishnan, N., Kumar,B.V.and Sivasubramanian, P., 2009. Bioefficacy of bifenthrin 10 EC against sucking insects, bollworms and natural enemies in cotton. Madras Agricultural Journal. 96(1/6): 225-229.

Bambhaniya, V.S., Khanpara, A.V. and Patel, H.N., 2018. Bio-Efficacy of insecticides against sucking pests; Jassid and Thrips infesting tomato. Journal of Pharmacognosy and Phytochemistry. 7(3): 1471-1479.

Bo, B.Y., 1992. IPM on cotton in Asia and the Pacific Region. The Pakistan Cotton. 36: 87-100.

Chinniah, C. and Ali, K., 2000. Relative efficacy of insecticides/acaricides against sucking pests of okra. Pest Manage. Economic Zoology., 8: 111-
116.

Eittipibool, W., Renou, A., Chongrattanameteekul, W. and Hormchan, P., 2001. Effects of Cotton Growth Regulator on Jassid Infestation and Injury. Kasetsart Journal (Natural Science). 35: 378-385.

Fleming, R. and Retnakaran, A., 1985. Evaluating single treatment data using Abbott's formula with modification. Journal of Economic Entomology. 78: 1179-1181. https://doi. org/10.1093/jee/78.6.1179

Frank, S.D., 2012. Reduced risk insecticides to control scale insects and protect natural enemies in the production and maintenance of urban landscape plants. Environmental Entomology.41: 377-386. https://doi.org/10.1603/EN11230

Gouda, B.P., Ashok, M.B., Navi, S.S., Doreswamy, C., 2014. Impact of integrated pest management technologies in rainfed cotton and created job opportunities for rural youth and farm women in the Mysore district of Karnataka. International Journal of Tropical Agriculture., 32(1-2):105-108.

Khan, S.M., 2011. Varietal performance and chemical control used astactics against sucking insect pests of cotton. Sarbad Journal of Agriculture. 27(2): 255-261.

Khan., H.A.A., Akram, W., Arshad, M., Hafeez. F., 2016. Toxicity and resistance of field collected Musca domestica (Diptera: Muscidae) against insect growth regulator insecticides. Parasitology Research. 115(4):1385-1390.

Korejo, A.K., Soomro, A.W., Mallah, G.H., Soomro, A.R. and Memon, A.M., 2000. Efficacy of various pesticides for thecontrol of insect pest complex of cotton and their cost benefit ratio. Pakistan Journal of Biological Sciences. 3: 1468-1471. https://doi.org/10.3923/ pjbs.2000.1468.1471

Krishnananda, N. and Agarwal, R.A., 1979. Sources of resistance to jassid, Amrasca devastans Distant in cotton. Indian journal of Entomology. 41: 177180.

Michaud, J.P. and Grant, A.K., 2003. IPMcompatibility of foliar insecticides for citrus: Indices derived from toxicity to beneficial insects from four orders. Journal of Insect Sciences. 3: 1828. https://doi.org/10.1673/031.003.1801

Qaisar, A., Gogi, D., Abbas, S., Karar, H., 2011. Performance of Imidacloprid, Thiomethoxam, Acetamaprid and a Biocontrol Agent 
(Chrysoperla carnea) Against Whitefly, Jassid and Thrips on Different Cotton Cultivars. World Journal of Zoology., 7 (2): 141-146.

Rawale, B.N., Kausale, P.P., Munde, A.T., Kedar, P.B., Sonkamble, M.M. and Waghmode, D.B., 2002. Efficacy of insecticides and neem seed extract against cotton bollworms on NHH-44. Journal of Soils and Crops. 12(1): 75-77.

Razaq, M., Suhail,A.,Aslam,M.,Arif,M.J., Saleem, M.A. and Khan, M.H.A., 2005. Evaluation of neonicotinoids and conventionalinsecticides against cotton jassid, Amrasca devastans (dist.) and cotton whitefly, Bemisia tabaci(Genn.) on cotton. Pakistan Entomologist. 27(1): 75-78.

Rudramuni, T., Reddy, K.M.S. and Kumar, C.T.A. 2011. Bio-efficacy of new insecticidal molecules against insect-pests of cotton. Journal of Farm Sciences. 1(1): 49-58.

Sabry, K.H. and El-Sayed, A.A., 2016. Biosafety of abiopesticide and some pesticides used on cottoncrop against green lacewing,Chrysoperla carnea(Stehens) (Neuroptera: Chrysopidae). Journal of Biopesticides. 4(8): 214-218

Sahito, H.A., Abro, G.H., Syed, T.S., Memon, S.A., Mal, B. and Kaleri, S., 2011. Screening of
Pesticides against Cotton Mealybug Phenacoccus solenopsis Tinsley and its Natural Enemies on Cotton Crop. International Research Journal of Biochemistry and Bioinformatics. 1(9): 232-236

Sahito, H.A., R. Solangi, T. Kousar, Z.H. Shah and W.M. Mangrio, 2016. Population fluctuation of aphids, Lipaphis erysimi (Kalt) with response of biological control under mustard field conditions. Journal of Entomological and Zoology Studies, 4: 326-331.

Sharma, H.C. and Pampapathy, G., 2006. Influence of transgenic cottons on the relative abundance and damage by target and non-target insect pests under different protection regimes in India. Crop Protection. 25: 800-813. https://doi. org/10.1016/j.cropro.2005.11.002

Singh, S. and Singh, S., 2007. Economic evaluation of pest management technologies for sustainable cotton production in Punjab. Agricultural Economics Research Review. 20: 77-86.

Solangi, B.K. and Lohar, M.K., 2007. Insecticides on the population of insect pests. Effect of some Sci., 6: 140-42. Asian Journal of Plant Science. 6: 920-926. https://doi.org/10.3923/ ajps.2007.920.926 